International Journal of Instruction

e-ISSN: 1308-1470 • www.e-iji.net
July $2018 \bullet$ Vol.11, No.3

p-ISSN: 1694-609X

pp. $663-680$

Received: 01/03/2018

Revision: 25/05/2018

Accepted: 31/05/2018

\title{
The Effects of Cooperative Learning on Mathematics Achievement in Turkey: A Meta-Analysis Study
}

\section{Sedat Turgut}

Dr., Bartin University, Faculty of Education, Turkey, sdtturgut42@hotmail.com

\author{
İlknur Gülşen Turgut \\ Res. Asst., Dumlupinar University, Faculty of Education, Turkey, \\ ilknurgulsen@gmail.com
}

In this research, the effects of cooperative learning on mathematics achievement in Turkey were examined by meta-analysis method. For this purpose, the average effect size value and the average effect size values of the moderator variables (cooperative learning technique, education level, learning domain and implementation period) were calculated. MetaWin and Comprehensive MetaAnalysis (CMA) statistical programs were used for the analysis. Based on the inclusion criteria, 59 effect size values for 47 studies were calculated. Hedges's g coefficient was used when the effect sizes were calculated and the confidence level was accepted as $95 \%$. The average effect size value was 0,840 with 0,077 standard error which was calculated by the random-effects model. As a result, the effects of cooperative learning on mathematics achievement is moderate and positive.

Keywords: cooperative learning, mathematics, achievement, meta-analysis, learning

\section{INTRODUCTION}

Cooperative learning is the learning model where the students work together as small groups and help to each other's learning (Slavin, 2015). Cooperative learning is a type of learning strategy in which face-to-face communication is provided and interpersonal tasks are presented to the students in addition to a determined learning opportunity in constructed groups (Johnson \& Johnson, 1994). In cooperative learning model, the activities based on cooperation within small groups in the classroom are carried out at maximum level (Richards \& Rodgers, 2001). Learning depends on the information exchange among group members. Each group member is both responsible for their own learning and being motivating for increasing the learning of other members in the group (Olsen \& Kagan, 1992). The purpose of students' cooperation is to achieve learning target.

Citation: Turgut, S., \& Gülșen Turgut, İ. (2018). The Effects of Cooperative Learning on Mathematics Achievement in Turkey: A Meta-Analysis Study. International Journal of Instruction, 11(3), 663-680. https://doi.org/10.12973/iji.2018.11345a 
Cooperative learning is an alternative classroom structure and it makes developing learning, positive peer relationships and positive attitude towards the school easier (Johnson \& Johnson, 1989). This learning model not only creates a learner centered environment but also helps teachers in classroom management (Sharan, 1994). The groups or group members are not active alone. The teachers also actively operate in constructing the groups. The teachers need to design the activities for providing the group members with fertile study conditions. Additionally, the group members need to have acquired some certain social skills to study with each other efficiently. From this viewpoint, the teachers should provide their students with acquiring some social skills.

Depending on the project structure, the groups can study for a few minutes or for a few months in cooperative learning (Slavin, 1997). Group members are responsible for both their own learning and the others. Any group members target the achievement of all other group members. Thus, a mutual commitment among group members develops (Stevens, 2008). Hence, the group members support and motivate each other. Peer relationships develop among group members. The students acquire some social skills.

Each group activity does not mean cooperative learning. An activity should include five main elements as positive interdependence, individual responsibility, supportive face-toface communication, social skills and evaluation of group process in order to be cooperative (Johnson \& Johnson, 1989; Johnson \& Johnson, 1999).

Positive interdependence is individual perceptions of setting connections with others anyway (Johnson \& Johnson, 1999). In cooperative learning, the works of each group member will help others. Each of the group members will think that anyone will not be able to achieve if they are not successful. The teacher can create positive interdependence among group members by determining learning tasks.

Personal responsibility includes evaluating and sharing each group member's performance with other group members. It is purposed to strengthen each group member in cooperative learning and the group members are regarded as responsible for the work they undertake (Johnson \& Johnson, 1999). Therefore, personal responsibility is motivating for group members. It provides increase of cooperation and information sharing among group members.

Face-to-face supportive interaction includes the behaviors of group members such as supporting each other's efforts, encouraging each other. Some cognitive activities arise when group members promote each other's learning (Johnson \& Johnson, 1999). The more face-to-face interaction is experienced among group members, the easier they understand each other's thinking processes and interact socially.

Social skills improve intrapersonal and interpersonal skills of the group members. Unqualified group members cannot perform an efficient cooperation (Johnson \& Johnson, 2009). The skills like leadership, communication, decision making, trust building should be taught to group members (Johnson \& Johnson, 1999). Each group member should be promoted for using these skills.

Evaluation of the group process includes at which degree the group members reached their objectives and how efficiently they maintained relationships (Johnson \& Johnson, 
1999). The group members decide on the beneficial behaviors and necessary activities. They determine the necessary activities that should be done during ongoing process. Thus, they can identify and solve existing problems. Thus, they can continue for reaching mutual objectives in a healthier way.

Cooperative learning is an overall concept used for maintaining and organizing in-class instruction (Johnson, Johnson \& Stanne, 2000). Different cooperative learning techniques are stated in the literature. The most common ones of these are as follow: learning together (LO), team-game-tournament (TGT), group research, constructive discussion, jigsaw, students teams achievement divisions (STAD), complex instruction, team assisted instruction, cooperative learning structures, and cooperation-assisted combined reading and writing (Johnson, Johnson \& Stanne, 2000). Each of these techniques has its own original rules. Some techniques are more rule-based whereas others are more flexible. The teachers can apply these techniques according to their teaching objectives.

There are numerous scientific studies investigating the effect of cooperative learning on mathematics achievement in Turkey. In these researches, effects of different cooperative learning techniques at different educational levels, with different samples and in different implementation periods have been investigated. Different results have been obtained by these independent researches. More extensive evaluations can be done by combining these researches. Hence, the researches will be able to holistically approach the subject and to direct their studies. At that point, the role of meta-analysis studies arises. By meta-analysis, results of similar studies done independently can be combined by statistical method and interpreted coherently (Cohen, Manion \& Morrison, 2007). Investigating the literature, there are meta-analysis studies examining the effect of cooperative learning on mathematics achievement. Çapar and Tarım (2015) examined the local and international studies done between 1988 and 2010 in their research. They calculated the overall effect of cooperative learning on attitude and achievement. In addition, they calculated and interpreted the effect of educational level, learning domain, cooperative learning technique and experiment period on achievement. Çelik (2013) examined the local studies between 2005 and 2011 in his study examining the effect of alternative instruction methods on mathematics achievement. He calculated the overall effect of 12 studies based on cooperative learning among alternative methods in his study. Şad, Kış and Demir (2017) calculated 16 cooperative learning-based studies' overall effect between 2006 and 2010 in their study examining the effect of modern learning approaches on mathematics achievement. When the studies are overviewed, it is seen that they examined the cooperative learning-based studies done before 2013. Thus, it can be said that a contemporary meta-analysis study is needed on this subject.

The local studies based on cooperative learning and done between 2000 and 2017 have been examined in this study. The overall effect of cooperative learning on mathematics achievement has been calculated and interpreted within this scope. Additionally, the effect of cooperative technique implemented, educational level, learning domain and implementation period on achievement has been calculated and the findings have been interpreted. 


\begin{abstract}
METHOD
Research Design

It is aimed to combine and statistically evaluate the findings of independent studies examining the effect of cooperative learning on mathematics in this research. Metaanalysis technique is used in the research. Meta-analysis provides an overall evaluation by the statistical analysis of quantitative data obtained in independent studies on a certain subject (Glass, 1976; Lipsey \& Wilson, 2001). Effect size value is used to reach standard values in the evaluation of the results of independent studies with meta-analysis (Mertens, 2010). This value reflects the size of the relationship between two variables (Ellis, 2010). Effect size value provides independent study result with being standardized and evaluated based on the same criterion. Some steps are followed in meta-analysis studies. First the problem is identified. Then problem-related literature is scanned. The studies reached in the literature are coded according to some certain criterion. After this stage, the statistical analysis of the studies is performed and the findings are interpreted (Pigott, 2012; Sánchez-Meca \& Marín-Martínez, 2010). The mentioned stages are performed in this study, as well.
\end{abstract}

\title{
Data Collection
}

The research data was collected between December 1, 2017 and January 15, 2018. The local researches examining the effect of cooperative learning on mathematics achievement comprised the data resources of the research. For accessing the related studies, Council of Higher Education (CoHE) National Thesis Center, National Academic Net and Information Center (ULAKBİM), Google Scholar and Education Resources Information Center (ERIC) databases were scanned by primarily "işbirlikli ögrenme ve matematik (Turkish equivalent of cooperative learning and mathematics)", "cooperative learning and mathematics" keywords. Then the keywords "birlikte öğrenme”, "takım-oyun-turnuva", "grup araştırması”, "yapılandırmacı tartışma”, "jigsaw”, "öğrenci takımları başarı bölümleri”, "karmaşık öğretim”, "takım destekli öğretim”, "işbirlikli öğrenme yapıları" (all are the Turkish equavalents of the following keywords) were written next to "mathematics" were scanned. Finally, "learning together", "teams-games-tournaments", "group investigation", "constructive controversy", "jigsaw", "student teams achievement divisions", "complex instruction", "team accelerated instruction" and "cooperative learning structures" keywords were written next to "mathematics" and scanned. In the end 80 studies were accessed. The studies that would be included in meta-analysis were chosen by following criterion.

1) The studies should be done between 2000 and 2017.

2) The studies should be done in Turkey.

3) The language of the studies should be either Turkish or English.

4) The studies should be open to access at CoHE, ULAKBIM, Google Scholar and ERIC databases.

5) The pre-test/post-test control grouped experimental pattern should be applied in the studies. 
6) Cooperative learning techniques should be implemented to the experiment group and traditional teaching methods should be implemented to the control group in the studies.

7) The statistical values of experiment and control groups that are necessary for calculating effect sizes such as average, standard deviation value, sample size etc. should be given should be given in the studies.

In accordance with these criteria, 80 studies were reached. It was identified that there were articles produced from post-graduate thesis among the studies and only the articles were included in meta-analysis within this scope. There are more than two experiment groups in some studies. For the studies in this context, the effect sizes were calculated as many as the experiment groups and these studies were coded by adding letters such as a, $\mathrm{b}, \mathrm{c}$ next to the study year. Consequently 47 studies were included in meta-analysis and 59 effect values were calculated in relation with these studies.

\section{Coding Data}

In terms of inclusion criteria, a coding form was created. Study number, study name, study year, study authors, study type, sample size, sample's educational level, learning domain, implementation period, sample sizes of experiment and control groups, mean, standard deviation values and validity-reliability information on measurement instruments were stated in the form. The information about the studies that would be examined through meta-analysis was separately coded by two researches to these forms. Then the forms were compared. No difference was found between two forms coded by researchers. By this means it was purposed to include the data of the studies in metaanalysis unerringly.

\section{Data Analysis}

There are two approaches as fixed effect model and random effect model for calculating effect sizes through meta-analysis (Borenstein, Hedges, Higgins \& Rothstein, 2009). The decision of which one of the two approaches will be used is made according to the distribution of effect sizes. Q statistics is used to calculate the distribution of these effect sizes. Q statistics tests the homogeneity of the calculated effect sizes (Hedges \& Olkin, 1985). If the distribution is homogenous at the end of Q statistics fixed effect model is used if it is heterogeneous random effect model is preferred (Ellis, 2010). One of the methods that can be used for testing distribution is $\mathrm{I}^{2}$ statistics. $\mathrm{I}^{2}$ statistics can provide more detailed results about distribution (Petticrew \& Roberts, 2006). The value calculated by $\mathrm{I}^{2}$ statistics is between $0 \%$ and $100 \%$. $25 \%$ represents low level of heterogeneity, $50 \%$ medium level of heterogeneity and $75 \%$ high level of heterogeneity (Cooper, Hedges \& Valentine, 2009). Both Q and $\mathrm{I}^{2}$ statistics were utilized in this study.

The normal distribution plot of the effect sizes was obtained by MetaWin program. Comprehensive Meta-Analysis (CMA) was used for funnel scatter plot, forest plot, publication bias, effect sizes and the analysis of moderator variables.

For determining publication bias, funnel plot and Rosenthal's fail-safe N (FSN) statistics were examined. It means that there is no bias if the effect sizes of the studies show a 
symmetrical distribution around overall effect size in funnel plot (Borenstein et al., 2009). The results are resistant to publication bias if the FSN value calculated as a result of fail-safe N statistics is larger than observed study number (Rosenthal, 1991). Meanly, as the FSN value increases, the possibility of bias decreases dependently. Additionally Mullen, Muellerleile and Bryant's (2001) suggestion -based on fail-safe N statistics- for using the formula $\mathrm{N} /(5 \mathrm{k}+10)$ ( $\mathrm{k}$ is the number of the studies included in meta-analysis) was assisted. The fact that the numerical value obtained through treatment based on the formula is larger than 1 means that the results are away from bias.

Hedge's g was used for calculating effect sizes and confidence level was accepted as 95\% in calculation. Interpreting the calculated effect sizes, the criteria was accepted like that it is weak if between 0 and 0.20 , it is small if between 0.21 and 0.50 , it is medium if between 0.51 and 1.00, and it is large if higher than 1 (Cohen et al., 2007, p. 521). The cooperative learning technique assisted in the study, learning domain, implementation period, educational level and sample size were determined as moderator variables.

\section{FINDINGS}

The descriptive statistics of the studies examining the effect of cooperative learning techniques on achievement in mathematics teaching process in Turkey is shown in Table 1 .

Table 1

The Descriptive Statistics of the Studies Examining the Effects of Cooperative Learning on Mathematics Achievement

\begin{tabular}{|c|c|c|c|}
\hline & & Frequency & Percentage $(\%)$ \\
\hline \multirow{3}{*}{ Study Type } & Article & 24 & $\% 51.06$ \\
\hline & Doctoral Dissertation & 2 & $\% 4.3$ \\
\hline & Master's Thesis & 21 & $\% 44.6$ \\
\hline \multirow{4}{*}{ Study Year } & $2000-2004$ & 6 & $\% 12.76$ \\
\hline & $2005-2009$ & 16 & $\% 34.04$ \\
\hline & $2010-2014$ & 12 & $\% 25.53$ \\
\hline & $2015-2017$ & 13 & $\% 27.65$ \\
\hline \multirow{4}{*}{ Education Level } & Elementary School & 20 & $\% 42.55$ \\
\hline & Middle School & 21 & $\% 44.68$ \\
\hline & Higher School & 3 & $\% 6.38$ \\
\hline & Undergraduate & 3 & $\% 6.38$ \\
\hline \multirow{3}{*}{ Learning Domain } & Mathematics & 30 & $\% 63.82$ \\
\hline & Geometry & 9 & $\% 19.14$ \\
\hline & $\begin{array}{l}\text { Mathematics and } \\
\text { Geometry }\end{array}$ & 8 & $\% 17.02$ \\
\hline \multirow{8}{*}{ Implementation Period } & $1-5$ hours & 1 & $\% 2.12$ \\
\hline & 6-10 hours & 2 & $\% 4.25$ \\
\hline & 11-15 hours & 3 & $\% 6.38$ \\
\hline & 16-20 hours & 10 & $\% 21.27$ \\
\hline & 21-25 hours & 4 & $\% 8.51$ \\
\hline & 26-30 hours & 3 & $\% 6.38$ \\
\hline & 31 or more hours & 4 & $\% 8.51$ \\
\hline & Unidentified & 20 & $\% 42.55$ \\
\hline Total & & 47 & 100 \\
\hline
\end{tabular}


Looking at Table 1, it is seen that 24 of the studies included in meta-analysis are articles $(51.6 \%), 21$ of them are master's thesis $(44.6 \%)$ and 2 of them are doctoral dissertations $(4.3 \%)$. In terms of years, the largest number of study was written between 2007 and 2017 ( 7 studies for each, 14.89\%). In terms of educational level, it can be stated that middle schools (21 studies, 44.68\%) and elementary schools (20 studies, 42.55\%) were mainly focused. 30 of the studies performed are related to mathematics $(63.82 \%), 9$ are related to geometry $(19.14 \%), 8$ are related to both mathematics and geometry $(17.02 \%)$ learning domains. In the studies where the implementation period was stated as hours, it is seen that 16-20 hours (10 studies, $21.27 \%$ ) of implementation was done majorly.

The Findings about the Effect of Cooperative Learning on Mathematics Achievement

Normal distribution plot was observed for determining the suitability of 47 studies' effect sizes for being combined by meta-analysis. Normal distribution plot of the study effect sizes is given in Figure 1.

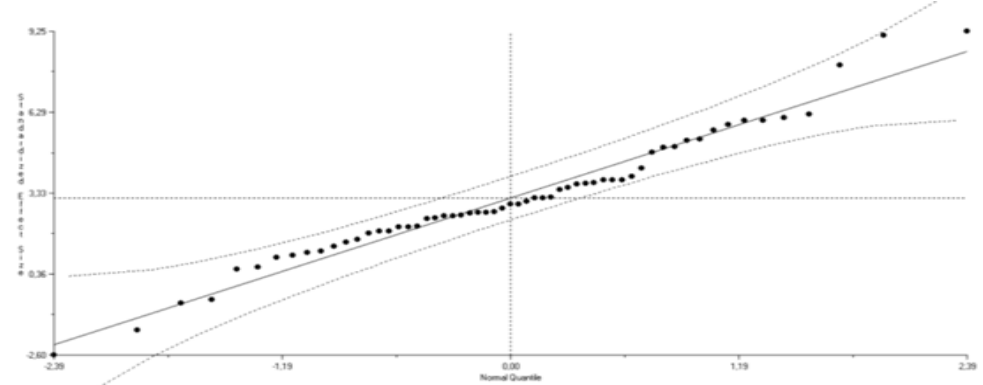

Figure 1

Normal distribution plot of the effect sizes of the studies included in meta-analysis

Investigating Figure 1, the effect sizes of studies distribute within the borders of pointed confidence interval shown by dotted line at the right and left sides of normal distribution line. Accordingly, it can be said that the effect sizes show normal distribution and they can be combined statistically by meta-analysis.

Funnel scatter plot of the studies included in meta-analysis is given in Figure 2 in order to determine the possibility of publication bias before calculating the effect sizes of the studies. 


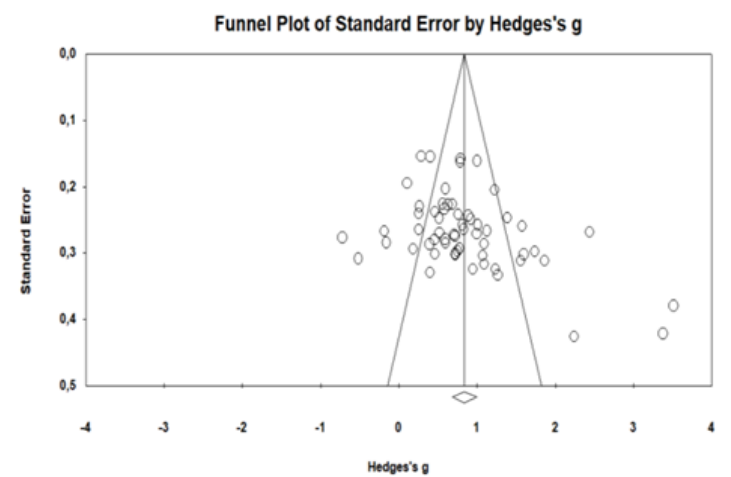

Figure 2

Funnel plot related to the effect sizes of the studies included in meta-analysis

Investigating Figure 2, it is shown that the effect sizes majorly scatter almostsymmetrically at the middle part of the funnel plot and at left and right sides of the vertical line indicating the combined effect size. Since the distribution is not absolutely symmetrical, Rosenthal's fail-safe N (FSN) statistics was assisted in order to determine the probability of publication bias. Statistical information is given in Table 2 .

Table 2

Rosenthal's FSN Statistics Results

\begin{tabular}{ll}
\hline Bias Condition & \\
\hline$Z$ value for observed studies & 24,16517 \\
\hline P value for observed studies & 0,00000 \\
\hline Alpha & 0,05 \\
\hline Direction & 2 \\
\hline$Z$ value for Alpha & 1,95996 \\
\hline Number of Observed Studies & 59 \\
\hline FSN & 8910 \\
\hline
\end{tabular}

As seen in Table 2, N (FSN) value was calculated as 891. According to $\mathrm{N} /(5 \mathrm{k}+10)$ formula (Mullen et al., 2001) $8910 /(5 * 59+10)$ the calculation is 29,213 . According to this calculation, it can be identified the studies included in meta-analysis are resistant to publication bias.

Homogeneity value for fixed effect model and random effect model, average effect sizes and confidence intervals are given in Table 3 in order to determine the model which will be selected for calculating effect sizes of the studies. 
Table 3

Average effect sizes and lower and upper values of confidence interval according to effect model

\begin{tabular}{|c|c|c|c|c|c|c|c|c|}
\hline \multirow[t]{2}{*}{ Model } & \multirow{2}{*}{$\begin{array}{l}\text { Average } \\
\text { Effect Size } \\
\text { Value (ES) }\end{array}$} & \multicolumn{2}{|c|}{$\begin{array}{l}\text { 95\% Confidence } \\
\text { Interval for Effect } \\
\text { Size }\end{array}$} & \multirow{2}{*}{$\begin{array}{l}\text { Standard } \\
\text { Error (SE) }\end{array}$} & \multirow{2}{*}{$\begin{array}{l}\text { Homogeneity } \\
\text { Value (Q) }\end{array}$} & \multirow{2}{*}{$\begin{array}{l}\text { Degree } \\
\text { of } \\
\text { Freedom }\end{array}$} & \multirow[t]{2}{*}{$\mathrm{I}^{2}$} & \multirow[t]{2}{*}{$\mathrm{p}$} \\
\hline & & $\begin{array}{l}\text { Lower } \\
\text { Bound }\end{array}$ & $\begin{array}{l}\text { Upper } \\
\text { Bound }\end{array}$ & & & & & \\
\hline Fixed & 0,761 & 0,697 & 0,825 & 0,033 & 339,497 & 58 & 82,916 & 0,000 \\
\hline Random & 0,840 & 0,683 & 0,997 & 0,080 & & & & \\
\hline
\end{tabular}

Looking at Table 3, the homogeneity value of the studies meta-analyzed according to fixed effect model was calculated as $\mathrm{Q}=339,497$. The critical value of 58 degree of freedom is 76,778 at chi-square table at $95 \%$ significance level. Consequently, it is seen that $\mathrm{Q}$ value is larger than the critical value $(339,497)$ that corresponds to 58 degree of freedom (for $\mathrm{df}=58 \mathrm{x}^{2}=76,778$ ) in chi-square table. Regarding this finding, it can be said that the studies meta-analyzed show a heterogeneous distribution. Additionally, I 2 value with $82.916 \%$ addresses high level of heterogeneity. Random effect model was preferred for calculating the average effect sizes of the studies meta-analyzed depending on this. The average effect size value calculated by random effect model is 0,840 with standard error 0,080. This effect size is at medium level according to Cohen et al. (2007). Regarding this, it can be said that cooperative learning positively affects mathematics achievement.

The forest plot illustrating the distribution of the effect sizes values of the studies metaanalyzed according random effect model is given in Figure 3. 


\section{Meta Analysis}

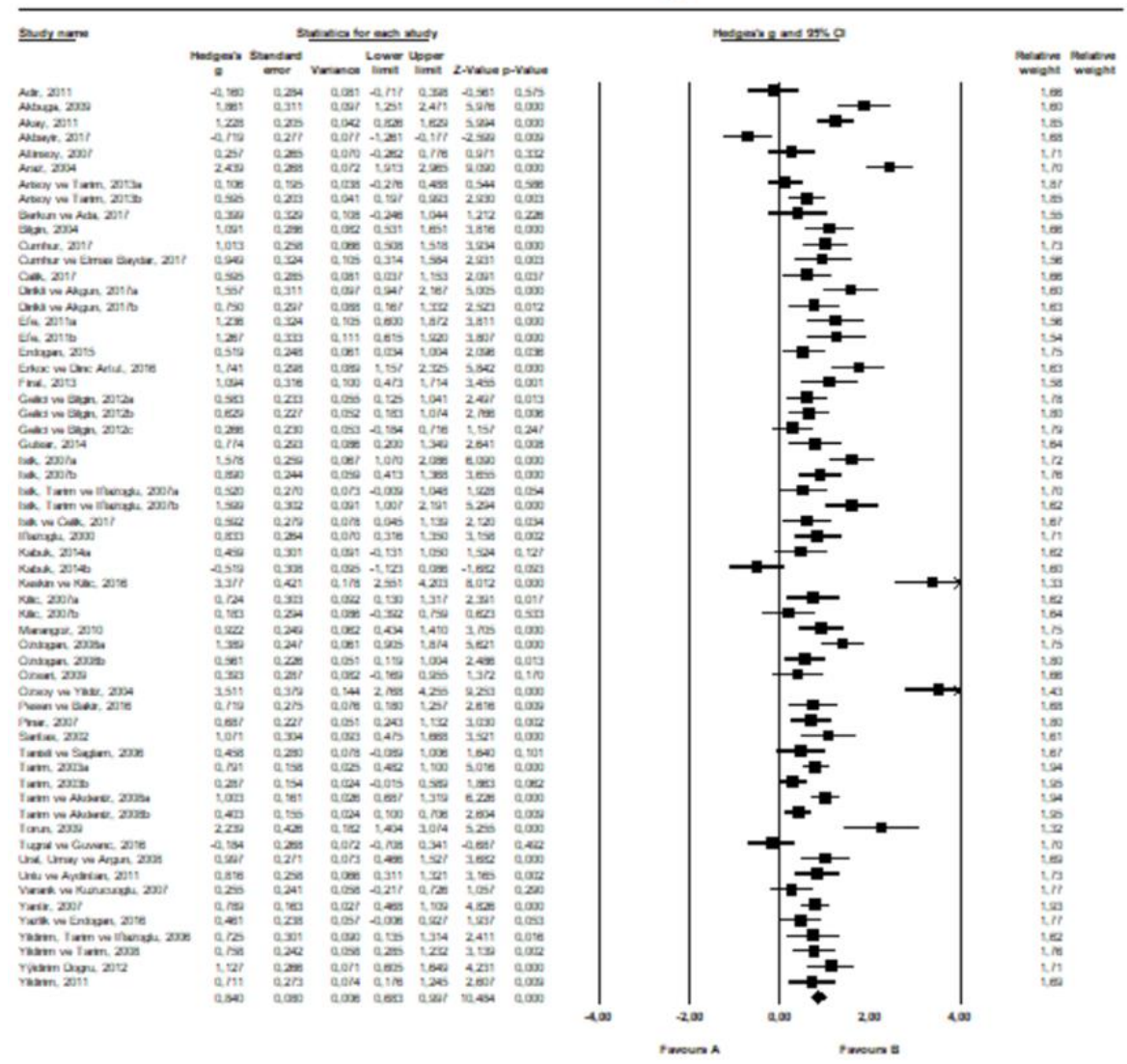

Figure 3

Forest plot of studies' effect sizes according to random effects model

The squares in Figure 3 indicate the effect sizes of the studies while the area of the square indicates the weight of the studies' effect sizes in overall effect size. The numerical values about these weights are given at the right part of the plot. The lines appearing at two sides of the squares represent the lower and upper bound of these effect sizes at $95 \%$ confidence interval. The rhomb at the lowest part of the squares shows overall effect size. It is seen that the smallest effect size is $-0,716$, the largest one is 3,511 when the calculated effect sizes are examined. 4 effect sizes values among 59 values are negative. Accordingly it can be said that the effect of implemented cooperative technique is on behalf of experiment group in 55 studies. 
The Findings about Effect Sizes in Terms of Implemented Cooperative Learning Technique

The effect sizes calculated in terms of implemented cooperative technique are given in Table 4.

Table 4

Effect size differences in terms of implemented cooperative learning technique

\begin{tabular}{|c|c|c|c|c|c|c|c|}
\hline \multirow{2}{*}{ Variable } & \multirow{2}{*}{$\begin{array}{l}\text { Homogeneity } \\
\text { Value Between } \\
\text { Groups }\left(Q_{B}\right)\end{array}$} & \multirow{2}{*}{$\mathrm{p}$} & \multirow{2}{*}{$\mathrm{n}$} & \multirow{2}{*}{$\begin{array}{l}\text { Average Effect } \\
\text { Size Value } \\
\text { (ES) }\end{array}$} & \multicolumn{2}{|c|}{$\begin{array}{l}95 \% \text { Confidence } \\
\text { Interval for Effect Size }\end{array}$} & \multirow{2}{*}{$\begin{array}{l}\text { Standard } \\
\text { Error (SE) }\end{array}$} \\
\hline & & & & & $\begin{array}{l}\text { Lower } \\
\text { Bound }\end{array}$ & $\begin{array}{l}\text { Upper } \\
\text { Bound }\end{array}$ & \\
\hline $\begin{array}{l}\text { Cooperative } \\
\text { Learning Technique }\end{array}$ & 24,996 & 0,000 & & & & & \\
\hline $\begin{array}{l}\text { Knowledge } \\
\text { Exchange Technique }\end{array}$ & & & 3 & 0,223 & $-0,174$ & 0,620 & 0,203 \\
\hline Learning Together & & & 7 & 0,953 & 0,238 & 1,669 & 0,365 \\
\hline $\begin{array}{l}\text { Supported by } \\
\text { Multiple Intelligence }\end{array}$ & & & 5 & 1,179 & 0,700 & 1,658 & 0,244 \\
\hline Pairs Check & & & 4 & 0,280 & $-0,140$ & 0,699 & 0,214 \\
\hline $\begin{array}{l}\text { Team-Assisted } \\
\text { Individualization }\end{array}$ & & & 8 & 0,814 & 0,141 & 0,537 & 1,090 \\
\hline $\begin{array}{l}\text { Student Teams } \\
\text { Achievement } \\
\text { Divisions } \\
\end{array}$ & & & 16 & 1,113 & 0,769 & 1,458 & 0,176 \\
\hline $\begin{array}{l}\text { Teams-Games- } \\
\text { Tournaments }\end{array}$ & & & 4 & 0,411 & 0,175 & 0,648 & 0,121 \\
\hline
\end{tabular}

The inter-groups homogeneity value $\left(\mathrm{Q}_{\mathrm{B}}\right)$ in terms of implemented cooperative technique was calculated as 24,996. The critical value of 6 degree of freedom is 12,592 in chi-square table at $95 \%$ significance level. It is seen that $\mathrm{Q}$ value is larger than the critical value that corresponds to 6 degree of freedom in chi-square table $\left(Q_{B}=24,996\right.$, $\mathrm{p}=0,000)$. Regarding this, there is a statistically significant difference between groups in terms of implemented cooperation technique. According to the findings, multiple intelligence-assisted cooperative technique and STAD have the maximum effect on mathematics achievement. According to Cohen et al. (2007) the calculated effect size values of these two techniques have a large level of effect. In addition, learning together and cluster-assisted individualization techniques' effect sizes are almost large.

\section{The Findings about Effect Sizes in Terms Educational Level}

The effect sizes calculated in terms of educational level are given in Table 5.

Table 5

Effect size differences in terms of educational level

\begin{tabular}{|c|c|c|c|c|c|c|c|}
\hline \multirow{2}{*}{ Variable } & \multirow{2}{*}{$\begin{array}{l}\text { Homogeneity } \\
\text { Value Between } \\
\text { Groups }\left(\mathrm{Q}_{\mathrm{B}}\right)\end{array}$} & \multirow{2}{*}{$\mathrm{p}$} & \multirow{2}{*}{$\mathrm{n}$} & \multirow{2}{*}{$\begin{array}{l}\text { Average Effect } \\
\text { Size Value } \\
\text { (ES) }\end{array}$} & \multicolumn{2}{|c|}{$\begin{array}{l}95 \% \text { Confidence } \\
\text { Interval for Effect Size }\end{array}$} & \multirow{2}{*}{$\begin{array}{l}\text { Standard } \\
\text { Error (SE) }\end{array}$} \\
\hline & & & & & $\begin{array}{l}\text { Lower } \\
\text { Bound }\end{array}$ & $\begin{array}{l}\text { Upper } \\
\text { Bound }\end{array}$ & \\
\hline $\begin{array}{l}\text { Educational } \\
\text { Level }\end{array}$ & 6,521 & 0,089 & & & & & \\
\hline $\begin{array}{l}\text { Elementary } \\
\text { School }\end{array}$ & & & 25 & 0,729 & 0,545 & 0,913 & 0,094 \\
\hline Middle School & & & 26 & 1,046 & 0,761 & 1,331 & 0,145 \\
\hline Higher School & & & 5 & 0,295 & $-0,337$ & 0,928 & 0,323 \\
\hline Undergraduate & & & 3 & 0,991 & 0,532 & 1,451 & 0,234 \\
\hline
\end{tabular}


The inter-groups homogeneity value $\left(\mathrm{Q}_{\mathrm{B}}\right)$ in terms of educational level was calculated as 6,521 . The critical value of 3 degree of freedom is 7,815 in chi-square table at $95 \%$ significance level. It is seen that $\mathrm{Q}$ value is smaller than the critical value that corresponds to 3 degree of freedom in chi-square table $\left(\mathrm{Q}_{B}=24,996, \mathrm{p}=0,000\right)$. Regarding this, there is not a statistically significant difference between groups in terms of educational level.

\section{The Findings about Effect Sizes in Terms of Learning Domain}

The effect sizes calculated in terms of learning domain are given in Table 6 .

Table 6

Effect size differences in terms of learning domain

\begin{tabular}{|c|c|c|c|c|c|c|c|}
\hline \multirow[t]{2}{*}{ Variable } & \multirow{2}{*}{$\begin{array}{l}\text { Homogeneity } \\
\text { Value Between } \\
\text { Groups }\left(Q_{B}\right)\end{array}$} & \multirow{2}{*}{$\mathrm{p}$} & \multirow[t]{2}{*}{$\mathrm{n}$} & \multirow{2}{*}{$\begin{array}{l}\text { Average } \\
\text { Effect Size } \\
\text { Value } \\
\text { (ES) }\end{array}$} & \multicolumn{2}{|c|}{$\begin{array}{l}95 \% \text { Confidence } \\
\text { Interval for Effect } \\
\text { Size }\end{array}$} & \multirow{2}{*}{$\begin{array}{l}\text { Standard } \\
\text { Error (SE) }\end{array}$} \\
\hline & & & & & $\begin{array}{l}\text { Lower } \\
\text { Bound }\end{array}$ & $\begin{array}{l}\text { Upper } \\
\text { Bound }\end{array}$ & \\
\hline $\begin{array}{l}\text { Learning } \\
\text { Domain }\end{array}$ & 6,452 & 0,040 & & & & & \\
\hline Mathematics & & & 37 & 0,823 & 0,594 & 1,052 & 0,117 \\
\hline Geometry & & & 11 & 1,101 & 0,858 & 1,344 & 0,124 \\
\hline $\begin{array}{l}\text { Mathematics } \\
\text { and Geometry }\end{array}$ & & & 11 & 0,643 & 0,380 & 0,907 & 0,135 \\
\hline
\end{tabular}

The inter-groups homogeneity value $\left(\mathrm{Q}_{\mathrm{B}}\right)$ in terms of learning domain was calculated as 6,452 . The critical value of 2 degree of freedom is 5,991 in chi-square table at $95 \%$ significance level. It is seen that $\mathrm{Q}$ value is larger than the critical value that corresponds to 2 degree of freedom in chi-square table $\left(\mathrm{Q}_{\mathrm{B}}=6,452, \mathrm{p}=0,040\right)$. Regarding this, there is a statistically significant difference between groups in terms of learning domain. According to Cohen et al. (2007) the calculated effect size values of geometry learning domain has a large level of effect.

\section{The Findings about Effect Sizes in Terms of Implementation Period}

The effect sizes calculated in terms of implementation period are given in Table 7.

Table 7

Effect size differences in terms of implementation period

\begin{tabular}{|c|c|c|c|c|c|c|c|}
\hline \multirow{2}{*}{ Variable } & \multirow{2}{*}{$\begin{array}{l}\text { Homogeneity } \\
\text { Value Between } \\
\text { Groups }\left(\mathrm{Q}_{\mathrm{B}}\right)\end{array}$} & \multirow{2}{*}{$\mathrm{p}$} & \multirow{2}{*}{$\mathrm{n}$} & \multirow{2}{*}{$\begin{array}{l}\text { Average Effect } \\
\text { Size Value } \\
\text { (ES) }\end{array}$} & \multicolumn{2}{|c|}{$\begin{array}{l}95 \% \text { Confidence Interval } \\
\text { for Effect Size }\end{array}$} & \multirow{2}{*}{$\begin{array}{l}\text { Standard } \\
\text { Error (SE) }\end{array}$} \\
\hline & & & & & $\begin{array}{l}\text { Lower } \\
\text { Bound }\end{array}$ & $\begin{array}{l}\text { Upper } \\
\text { Bound }\end{array}$ & \\
\hline $\begin{array}{l}\text { Implementation } \\
\text { Period }\end{array}$ & 10,594 & 0,060 & & & & & \\
\hline $11-15$ hours & & & 3 & 0,318 & $-0,207$ & 0,842 & 0,268 \\
\hline 16-20 hours & & & 12 & 0,838 & 0,377 & 1,300 & 0,235 \\
\hline $21-25$ hours & & & 8 & 0,659 & 0,393 & 0,926 & 0,136 \\
\hline 26-30 hours & & & 3 & 0,490 & $-0,817$ & 1,797 & 0,667 \\
\hline 31 or more hours & & & 5 & 0,519 & 0,257 & 0,781 & 0,134 \\
\hline Unidentified & & & 25 & 0,998 & 0,766 & 1,229 & 0,118 \\
\hline
\end{tabular}


The inter-groups homogeneity value $\left(\mathrm{Q}_{\mathrm{B}}\right)$ in terms of implementation period was calculated as 10,594 . The critical value of 5 degree of freedom is 11,070 in chi-square table at $95 \%$ significance level. It is seen that Q value is smaller than the critical value that corresponds to 5 degree of freedom in chi-square table $\left(Q_{B}=10,594, p=0,060\right)$. Regarding this, there is not a statistically significant difference between groups in terms of implementation period.

\section{DISCUSSION, CONCLUSION AND SUGGESTIONS}

59 effect sizes of 47 studies were calculated in this study examining the effect of cooperative learning on mathematics achievement. 4 of these values are negative and other 55 are positive. This result points out that the implemented cooperative learning techniques are on behalf of experiment group in 55 studies. In other words, cooperative learning positively affected mathematics achievement in 55 studies. The average effect size value calculated according to random effect model is 0,840. This value means medium level of effect according to Cohen et al. (2007). Accordingly, it can be stated that cooperative learning techniques increase mathematics achievement. This result is similar to the results revealed by Şad, Kış and Demir (2017), Çapar and Tarım (2015), Çelik (2013) and Tarım (2003).

The implemented cooperative learning technique, educational level, learning domain and implementation period of the studies included in meta-analysis were identified as moderator variables and effects sizes according to these variables were calculated. Thus, it was tested whether the effect of cooperative learning on mathematics statistically differed in terms of moderator variables.

In terms of the implemented cooperative technique, multiple intelligence-assisted cooperative technique $(\mathrm{ES}=1,179)$ and $\mathrm{STAD}$ technique $(\mathrm{ES}=1,113)$ have the maximum effect on mathematics achievement. Learning together $(\mathrm{ES}=0,953)$ and cluster-assisted individualization $(E S=0,814)$ techniques follow these. Çapar and Tarım (2015) have stated that the most effective cooperative techniques are learning together, unconstructed and STAD in their study. It is identified that STAD is effective in both studies.

Any statistically significant difference between groups cannot be found in terms of the educational level where cooperative learning techniques are implemented. Regarding this, it is understood that cooperative learning has the same effect on mathematics achievement at elementary, middle school, high school and undergraduate levels. This result is consistent with the study results of Şad, Kış and Demir'in (2017) while it is different from the study results of Çapar and Tarım (2015). Çapar and Tarım (2015) found out that cooperative learning majorly effective at undergraduate level in their studies.

A statistically significant difference between groups was found in terms of the learning domain cooperative learning was implemented. Accordingly, cooperative learning is mostly effective in geometry. This result is consistent with the study results of Çelik (2013). 
A statistically significant difference cannot be found in terms of implementation period between groups. Thus, it can be said that different implementation periods in cooperative teaching have similar effect on mathematics achievement. Çapar and Tarım (2015) reached similar findings in their study.

In this study, the effect of cooperative learning on mathematics achievement was examined. The effect of cooperative learning on self-efficacy, attitude and motivation can be examined in future researches. Only the studies done in Turkey were examined in the research. More extended results can be obtained by accessing international studies.

\section{REFERENCES}

The references marked with asterisk (*) demonstrate the studies included in meta-analysis.

*Adır, T. (2011). Öge gösterim teorisi modeli ile bilgi değişim tekniğinin birlikte kullanılmasinn matematik ögretimindeki etkililiğinin araşttrilması (Unpublished master's thesis). Firat University, Elazığ.

"Akay, G. (2011). The effect of peer instruction method on the 8th grade students" mathematics achievement in transformation geometry and attitudes towards mathematics (Unpublished master's thesis). Middle East Technical University, Ankara.

*Akbayır, K. (2017). İşbirlikli öğrenme yönteminin 9.sınıf öğrencilerinin matematik dersi "kümeler" konusunun öğretimindeki etkililiği. Turkish Studies, 12(17), 1-14.

*Akbuğa, S. (2009). İlköğretim 4. sinlf matematik dersinde işbirlikli öğrenme ilkelerine göre yapılandırlmış grup etkinliklerinin ögrenci erişilerine ve tutumlarına etkisi (Unpublished master's thesis). Dokuz Eylül University, İzmir.

"Altınsoy, B. (2007). Takım-oyun turnuvalart tekniğinin ilkögretim dördüncü sinvf öğrencilerinin matematik dersindeki akademik başarlsı, kalıcllı ve matematiğe iliş̧kin tutumları üzerindeki etkisi (Unpublished master's thesis). Çukurova University, Adana.

*Araz, S. G. (2004). Illkögretim 6. sinıfta kesirlerin ondalık gösterimi ünitesinin ögretilmesinde işbirlikli ögrenme yönteminin geleneksel yönteme göre öğrenci başarısina etkisi (Unpublished master's thesis). Dokuz Eylül University, İzmir.

*Arısoy, B. ve Tarım, A. (2013). İşbirlikli öğrenme yönteminin öğrencilerin akademik başarı, kalıcılık ve sosyal beceri düzeylerine etkisi. Hacettepe Üniversitesi Eğitim Fakültesi Dergisi, 28(3), 1-14.

"Berkün, D. N. ve Ada, T. (2017). Permütasyon ve olasllık konusunun öğretiminde bilgi değişme tekniğinin kullanılmasının akademik başarıya ve hatırda tutma düzeyine etkisinin incelenmesi. Kastamonu Eğitim Dergisi, 25(6), 2295-2310.

"Bilgin, T. (2004). İlköğretim yedinci sınıf matematik dersinde (çokgenler konusunda) öğrenci takımları başarı bölümleri tekniğinin kullanımı ve uygulama sonuçları. Uludă̆ Üniversitesi Ĕgitim Fakültesi Dergisi, XVII(1), 19-28.

Borenstein, M., Hedges, L. V., Higgins, J. P. T., \& Rothstein, H. R. (2009). Introduction to meta-analysis. UK: John Wiley \& Sons, Ltd., Publications.

Cohen, L., Manion, L., \& Morrison, K. (2007). Research methods in education. New York: Routledge.

Cooper, H., Hedges, L. V., \& Valentine, J. C. (2009). The handbook of research synthesis and meta-analysis. New York: Russell Sage Publication. 
*Cumhur, F. (2017). Matematik öğretiminde birlikte öğrenme tekniğinin kullanılması ve değerlendirilmesi. Karaelmas Journal of Educational Sciences, 5, 285-295.

*Cumhur, F. ve Elmas Baydar, H. (2017). İşbirlikli Öğrenme yönteminin EBOB-EKOK konusu öğretimindeki etkililiği. Kastamonu Ĕ̆itim Dergisi, 25(5), 1663-1680.

${ }^{*}$ Çalık, A. V. (2017). İşbirlikli ögrrenme yöntemlerinden jigsaw tekniğinin 7. sinıf dörtgenler konusunda etkililiği. (Unpublished master's thesis). Kastamonu University, Kastamonu.

Çapar, G., \& Tarım, K. (2015). Efficacy of the cooperative learning method on mathematics achievement and attitude: A meta-analysis research. Educational Sciences: Theory \& Practice, 15(2), 553-559. DOI: 10.12738/estp.2015.2.2098

Çelik, S. (2013). İlköğretim matematik derslerinde kullanılan alternatif öğretim yöntemlerinin akademik başarıya etkisi. Bir meta analiz çalışması (Unpublished master's thesis). Eskişehir Osmangazi University, Eskişehir.

"Dirikli, M., \& Akgün, L. (2017). The effect of cooperative learning methods on pre service elementary mathematics teachers' academic achievement and retention in the subject of analytical examination of the circle. Çukurova Üniversitesi Eğitim Fakültesi Dergisi, 46(2), 427-440.

*Efe, M. (2011). İşbirlikli öğrenme yönteminin, öğrenci takımları başarı bölümleri ve küme destekli bireyselleştirme tekniklerinin ilkögretim 7. sınıf öğrencilerinin matematik dersi "istatistik ve olasılı" ünitesindeki başarllarına, tutumlarına ve motivasyonlarına etkisi (Unpublished master's thesis). Mustafa Kemal University, Hatay.

Ellis, P. D. (2010). The essential guide to effect sizes. Statistical power, meta-analysis, and the interpretation of research result. New York: Cambridge University Press.

*Erdoğan, F. (2015). Isşbirlikli öğrenme yönteminin ilkokul 4. sinıf matematik dersinde ögrencilerin akademik başarılarına ve üst bilişsel farkındalıklarına etkileri (Unpublished master's thesis). Dokuz Eylül University, İzmir.

*Erkoç, A. ve Dinç Artut, P. (2016). Küme destekli bireyselleştirme tekniğinin 8. sınıf öğrencilerinin geometri başarılarına ve kalıcılığa etkisi. Hacettepe Üniversitesi Eğitim Fakültesi Dergisi, 31(1), 1-13.

*Fırat, Ü. (2013). Ortaokul 3. sinıf matematik dersinde uygulanan öğrenci takımları başarı bölümleri tekniğinin öğrencilerin akademik başarısı ve tutumuna etkisi (Unpublished master's thesis). Atatürk University, Erzurum.

*Gelici, Ö. ve Bilgin, İ. (2011). İşbirlikli öğrenme tekniklerinin öğrencilerin cebir öğrenme alanındaki başarı, tutum ve eleştirel düşünme becerilerine etkileri. Abant İzzet Baysal Üniversitesi Eğitim Fakültesi Dergisi, 12(1), 9-32.

Glass, G. V. (1976). Primary, secondary, and meta-analysis of researh. Educational Researcher, 5(10), 3-8.

*Gülsar, A. (2014). İşbirlikli öğrenmenin matematik başarısına etkisi ve bu yönteme ilişkin öğrenci görüşleri (Unpublished master's thesis). Uludağ University, Bursa.

Hedges, L. V., \& Olkin, I. (1985). Statistical methods for meta-analysis. Orlando, Florida: Academic Press Inc.

*Işık, D. (2007). Çoklu zekâ kuramı destekli kubaşık öğrenme yönteminin ilköğretim dördüncü sınıf öğrencilerinin matematik dersindeki akademik başarılarına ve kalıcılığa etkisi (Unpublished master's thesis). Çukurova University, Adana. 
*Işık, D., Tarım, K., ve İflazoğlu, A. (2007). Çoklu zekâ kuramı destekli kubaşık öğrenme yönteminin ilköğretim 3. sınıf öğrencilerinin matematik dersindeki akademik başarılarına etkisi. Ahi Evran Üniversitesi Kırşehir Eğitim Fakültesi Dergisi (KEFAD), 8(1), 63-77.

*Işık, A. ve Çelik, E. (2017). Rasyonel sayılar öğrenme alanında işbirlikli öğrenmenin akademik başarıya etkisi. Uluslararası Ĕgitim Bilimleri Dergisi, 4(11), 369-386.

*Iflazoğlu, A. (2000). Küme destekli bireyselleştirme tekniğinin temel eğitim beşinci sınıf öğrencilerinin matematik başarısı ve matematiğe ilişkin tutumları üzerindeki etkisi. Çukurova Üniversitesi Sosyal Bilimler Enstitüsü Dergisi, 6(6), 159-172.

Johnson, D. W., \& Johnson, R. T. (1989). Cooperation and competition: Theory and research. Edina, MN: Interaction Books.

Johnson, D. W., \& Johnson, R. T. (1994). Learning together. In S. Sharon. (Ed.), The handbook of cooperative learning methods (pp. 55-65). Westport, CT: Praeger Publishers.

Johnson, D. W., \& Johnson, R. T. (1999). Making cooperative learning work. Theory Into Practice, 38(2), 67-73.

Johnson, D.W., \& Johnson, R. T. (2009). An educational psychology success story: Social interdependence theory and cooperative learning. Educational Researcher, 38(5), 365-379.

Johnson, D.W., Johnson, R. T., \& Stanne, M. B. (2000). Cooperative learning methods: A Meta-analysis. $\quad 8 \quad$ Şubat $\quad 2018 \quad$ tarihinde https://www.researchgate.net/profile/David_Johnson50/publication/220040324_Cooperative _learning_methods_A_meta-analysis/links/00b4952b39d258145c000000/Cooperativelearning-methods-A-meta-analysis.pdf adresinden erişildi.

*Kabuk, Ö. (2014). İşbirlikli öğrenmeye dayall tekniklerin öğrencilerin matematik başarısına etkisinin incelenmesi (Unpublished master's thesis). Mehmet Akif Ersoy University, Burdur.

*Keskin, S. ve Kılı̧, D. (2016). Ortaokul 7. sınıf matematik dersinde olasılık konusunun işbirlikli ögrenme yöntemiyle öğretiminin öğrencilerin akademik başarılarına etkisi. Atatürk Üniversitesi Sosyal Bilimler Enstitüsü Dergisi, 20(3), 1173-1183.

*Kılıç, R. (2007). Webquest destekli işbirlikçi öğrenme yönteminin matematik dersindeki tutum ve erişiye etkisi (Unpublished master's thesis). Eskişehir Osmangazi University, Eskişehir.

Lipsey, M. W., \& Wilson, D. B. (2001). Practical meta-analysis. Thousand Oaks, CA: Sage publications.

*Marangoz, İ. (2010). İlköğretim 6. sinıf matematik dersi geometri öğrenme alanında işbirlikli ögrenme yönteminin ögrenci başarısı ve tutumlarına etkisi (Unpublished master's thesis). Gazi University, Ankara.

Mertens, D. M. (2010). Research and evaluation in education and psychology: Integrating diversity with quantitative, qualitative, and mixed methods. USA: Sage publications.

Mullen, B., Muellerleile, P., \& Bryant, B. (2001). Cumulative meta-analysis: A consideration of indicators of sufficiency and stability. Personality and Social Psychology Bulletin, 27(11), 1450-1462.

Olsen, R., \& Kagan, S. (1992). About cooperative learning. In C. Kessler (Ed.), Cooperative language learning: A teacher's resource book (pp. 1-30). Englewood Cliffs, CO: Prentice Hall Regents. 


\begin{abstract}
*Özdoğan, E. (2008). İşbirlikli öğrenme yönteminin ilköğretim 4. sınıf matematik öğretiminde öğrenci tutum ve başarısına etkisi: bilgisayar destekli işbirlikli öğrenme ve küme destekli bireyselleştirme tekniği (Unpublished master's thesis). Ege University, İzmir.

*Özsarı, T. (2009). İlkögretim 4. sınıf ögrencileri üzerinde işbirlikli öğrenmenin matematik başarısı üzerine etkisi: Probleme dayalı ögrenme (PDÖ) ve öğrenci takımları-başarı bölümleri (ÖTBB) (Unpublished master's thesis). Ege University, İzmir.

"Özsoy, N. ve Yıldız, N. (2004). “İşbirlikli öğrenme” yönteminin ilköğretim 7.sınıf matematik öğretiminde öğrenci başarısı üzerine etkisi. The Turkish Online Journal of Educational Technology, 3(3), 49-54.

*Pesen, A. ve Bakır, B. (2016). İşbirliğine dayalı öğrenme yaklaşımının 6. sınıf öğrencilerinin matematik dersi alan konusundaki başarılarına etkisi. Uluslararası Eğitim Programları ve Öğretim Çalışmaları Dergisi, 6(11), 71-84.

Petticrew, M., \& Roberts, H. (2006). Systematic reviews in the social sciences. A practical guide. Malden, MA: Blackwell Publishing.

"Pınar, S. (2007). "Ölçüler" konusunun eğitim teknolojileri ve işbirlikli öğrenme yöntemleriyle ögrrenilmesinin ögrencilerin matematik başarılarına etkisi (Unpublished master's thesis). Marmara University, İstanbul.
\end{abstract}

Pigott, T. (2012). Advances in meta-analysis. New York: Springer Science \& Business Media.

Rosenthal, R. (1991). Meta-analytic procedures for social research. California: Sage Publication.

Richards, J. C. \& Rodgers, T. S. (2001). Approaches and methods in language teaching. UK: Cambridge University Press.

*Sarıtaş, E. (2002). İşbirlikli ve geleneksel sınıflardaki başarılı ve başarısız problem çözücülerin kullandıkları öğrenme stratejileri, tutumları ve edim düzeyleri (Unpublished doctoral dissertation). Dokuz Eylül University, İzmir.

Sánchez-Meca, J., \& Marín-Martínez, F. (2010). Meta analysis. In P. Peterson, E. Baker, \& B. McGaw (Eds.), International encyclopedia of education (Vol. 7, pp. 274-282). Oxford: Elsevier.

Sharan, S. (1994). Cooperative learning and the teacher. In S. Sharan (Ed.), The handbook of cooperative learning methods (pp. 336-348). Westport, CT: Greenwood Publishing Group.

Slavin, R. E. (2015). Cooperative learning in elementary schools. Education 3-13,43(1), 514. DOI: $10.1080 / 03004279.2015 .963370$

Slavin, R. E. (1997). Co-operative learning among students. In D. Stern \& G. L. Huber (Eds.), Active learning for students and teachers (pp. 159-173). Frankfurt am Main: Peter Lang.

Stevens, R. J. (2008). Cooperative learning and literacy instruction in middle level education. In R. M. Gillies, A. Ashman, \& J. Terwel (Eds.), The teacher's role in implementing cooperative learning in the classroom (pp. 92-109). New York: Springer.

Şad, S. N., Kış, A., \& Demir, M. (2017). A meta-analysis of the effect of contemporary learning approaches on students' mathematics achievement. Hacettepe Üniversitesi Eğitim Fakültesi Dergisi, 32(1), 209-227. doi: 10.16986/HUJE.2016017222 
*Tanışlı, D. ve Sağlam, M. (2006). Matematik öğretiminde işbirlikli öğrenmede bilgi değişme tekniğinin etkililiği. Eğitimde Kuram ve Uygulama, 2(2), 47-67.

*Tarım, K. (2003). Kubaşık öğrenme yönteminin matematik öğretimindeki etkinliği ve kubaşık ögrenme yöntemine ilişkin bir meta analiz çalışması (Unpublished doctoral dissertation). Çukurova University, Adana.

*Tarim, K., \& Akdeniz, F. (2008). The effects of cooperative learning on Turkish elementary students9 mathematics achievement and attitude towards mathematics using TAI and STAD. Educational Studies in Mathematics, 67(1), 77-91.

*Torun, Ö. (2009). Çoklu zekâ destekli kubaşık öğrenme yönteminin ilköğretim 7. sinıf ögrencilerinin matematik dersi "geometrik cisimler" konusundaki başarı ve kalıcılı̆̆a etkisi (Unpublished master's thesis). Gazi University, Ankara.

*Tuğral, Z. ve Güvenç, H. (2016). İşbirlikli öğrenmenin lise öğrencilerinin matematik özyeterlik algıları, başarı ve etkin katılımlarına etkileri. Ahi Evran Üniversitesi Kırşehir Eğitim Fakültesi Dergisi (KEFAD), 17(2), 259-274.

*Ural, A., Umay, A. ve Argün, Z. (2008). Öğrenci takımları başarı bölümleri tekniği temelli eğitimin matematikte akademik başarı ve özyeterliğe etkisi. Hacettepe Üniversitesi Eğitim Fakültesi Dergisi, 37, 307-318.

*Ünlü, M. ve Aydıntan, S. (2011). İşbirlikli öğrenme yönteminin 8. sınıf öğrencilerinin matematik dersi "permütasyon ve olasılık" konusunda akademik başarı ve kalıcılık düzeylerine etkisi. Ahi Evran Üniversitesi Ĕ̈itim Fakültesi Dergisi, 12(3), 1-16.

*Varank, İ., ve Kuzucuoğlu, G. (2007). İşbirlikli öğrenmede birlikte öğrenme tekniğinin öğrencilerin matematik başarılarına ve işbirliği içinde çalışma becerilerine etkisi. Illköğretim Online, 6(3), 323-332.

*Yantır, N. (2007). İlköğretim matematik öğretmenliği ögrencilerinin işbirlikli öğrenme yöntemiyle geometri dersine ilişkin erişi düzeylerinin belirlenmesi (Unpublished master's thesis). Dokuz Eylül University, İzmir.

*Yazlık, D. Ö. ve Erdoğan, A. (2016). İşbirlikli öğrenme ile birlikte kullanılan problem çözme stratejilerinin öğrenci başarısı üzerine etkisi. Ahi Evran Üniversitesi Kırşehir Eğitim Fakültesi Dergisi (KEFAD), 17(3), 1-16.

${ }^{*} Y$ 1ldırım, Z. (2011). Kubaşık öğrenme yönteminin küme destekli bireyselleştirme tekniğinin 6. sını ögrencilerinin matematik dersindeki başarllarına ve tutumlarına etkisi (Unpublished master's thesis). Atatürk University, Erzurum.

*Yıldırım Doğru, E. (2012). Matematik öğretiminde kullanılan ayrılıp birleşme tekniğinin ögrencilerin özyeterlilik, kaygl ve kalıcılık düzeylerine etkisi (Unpublished master's thesis). Akdeniz University, Antalya.

*Yıldırım, K., Tarım, K. ve İflazoğlu, A. (2006). Çoklu zekâ kuramı destekli kubaşık öğrenme yönteminin matematik dersindeki akademik başarı ve kalıcılığa etkisi. Eğitimde Kuram ve Uygulama, 2(2), 81-96.

*Yıldırım, K. ve Tarım, K. (2008). Çoklu zekâ kuramı destekli kubaşık öğrenme yönteminin ilköğretim beşinci sınıf matematik dersinde akademik başarı ve hatırda tutma düzeyine etkisi. Ilköğretim Online 7(1), 174-187. 